\title{
PERAN KETERLIBATAN KARYAWAN PADA HUBUNGAN REWARDS DAN INTERNAL COMMUNICATION DENGAN ORGANIZATIONAL CITIZENSHIP BEHAVIOUR
}

\section{Made Dena Julio Mahendra Saputra ${ }^{1}$ Putu Saroyini Piartrini²}

\author{
${ }^{1,2}$ Fakultas Ekonomi dan Bisnis Universitas Udayana (Unud), Bali, Indonesia \\ E-mail: denadenux17@gmail.com
}

\begin{abstract}
ABSTRAK
Tujuan penelitian ini adalah untuk mengetahui efek mediasi keterlibatan karyawan pada hubungan rewards dan komunikasi internal dengan organizational citizenship behavior. Penelitian ini dilakukan di Akana Boutique Hotel. Jumlah sampel yang diambil sebanyak 50 orang karyawan, dengan menggunakan teknik sampel jenuh. Pengumpulan data dilakukan melalui kuesioner. Teknik analisis yang digunakan adalah regresi linear sederhana. Berdasarkan hasil analisis ditemukan bahwa 1). Rewards dan komunikasi internal berpengaruh positif dan signifikan terhadap keterlibatan karyawan, 2). Rewards, komunikasi internal dan keterlibatan karyawan berpengaruh positif dan signifikan terhadap organizational citizenship behavior, 3). Keterlibatan karyawan memediasi pengaruh rewards dan komunikasi internal terhadap organizational citizenship behavior, Semakin tinggi rewards, komunikasi internal dan keterlibatan karyawan maka organizational citizenship behavior juga akan semakin meningkat pada perusahaan Akana Boutique Hotel.
\end{abstract}

Kata kunci: rewards, komunikasi internal, keterlibatan karyawan, organizational citizenship behavior

\begin{abstract}
The purpose of this study was to determine the effect of mediating employee involvement on rewards relationships and internal communication with organizational citizenship behavior. This research was conducted at Akana Boutique Hotel. The number of samples taken was 50 employees, using saturated sample techniques. Data collection is done through a questionnaire. The analysis technique used is simple linear regression. Based on the results of the analysis found that 1). Rewards and internal communication have a positive and significant effect on employee engagement, 2). Rewards, internal communication and employee involvement have a positive and significant effect on organizational citizenship behavior, 3). Employee involvement mediates the effects of rewards and internal communication on organizational citizenship behavior, the higher rewards, internal communication and employee involvement, the organizational citizenship behavior will also increase in Akana Boutique Hotel companies.
\end{abstract}

Keywords: rewards, internal communication, employee involvement, organizational citizenship behavior 


\section{PENDAHULUAN}

Akana Boutique Hotel adalah salah satu hotel bintang empat yang terletak di Jalan Sudamala no. 17 Sanur Denpasar, memiliki 36 kamar dan mempekerjakan karyawan sebanyak 50 orang. Survey awal yang melibatkan lima orang karyawan mengungkapkan bahwa "rasa saling membantu antar karyawan rendah" (Eka, nama asli disamarkan). "Upah bulanan yang diterima yaitu sebesar Rp. 2.000.000” (Dwi, nama asli disamarkan). "keterlibatan karyawan dalam kegiatan-kegiatan diluar tugas pokok yang diadakan hotel kurang" (Tri, nama asli disamarkan). "Interaksi antar antar karyawan rendah" (Catur, nama asli disamarkan). "komunikasi antara atasan dan karyawan kurang" (Panca, nama asli disamarkan).

Hasil wawancara yang mengungkapkan bahwa rasa saling membantu antar karyawan rendah, menunjukkan Organizational Citizenship Behavior (OCB) dalam organisasi tersebut. Garay (2006:34) menjelaskan bahwa Organizational Citizenship Behaviour merupakan perilaku sukarela dari seseorang pekerja untuk mau melakukan tugas atau pekerjaan di luar tanggung jawab atau kewajibannya demi kemajuan atau keuntungan organisasinya. Menurut Waspodo dan Lussy (2012) menjelaskan bahwa Organizational Citizenship Behaviour merupakan bentuk perilaku yang merupakan pilihan dan insiatif individual, tidak berkaitan dengan sistem rewards formal organisasi. OCB merupakan kontribusi yang mendalam melebihi tuntutan peran di tempat kerja dan diberikan penghargaan oleh perusahaan atas tugas yang telah dilaksanakan (Paramita, 2012). Organizational Citizenship Behaviour merupakan kunci kesuksesan suatu organisasi, misalnya ketika timbal balik yang dirasakan karyawan tidak sesuai dengan apa yang 
diharapkan, maka akan berdampak pada berkurangnya niat karyawan untuk menjalankan perilaku Organizational Citizenship Behaviour. Karyawan yang sering bekerja over time dapat bekerja lebih efisien dari segi waktu maupun tenaga apabila dapat memunculkan perilaku Organizational Citizenship Behaviour (Firdaus, 2010). Penelitian yang dilakukan Tufail et al. (2017) mengatakan Organizational Citizenship Behaviour dipengaruhi oleh rewards secara positif dan signifikan.

Hasil wawancara juga terungkap bahwa upah bulanan yang diterima yaitu sebesar Rp. 2.000.000, tidak sesuai dengan harapan karyawan tersebut dan juga pengupahan lebih rendah dari ketentuan upah minmum kota Denpasar tahun 2018. Merujuk pada Peraturan Gubernur Bali Nomer 63 Tahun 2017 Tentang Upah Minimum Kabupaten Kota menyebutkan "Upah minmum kota Denpasar tahun 2018 yang sebesar Rp. 2.363.000”. Undang-Undang Republik Indonesia No. 13 Tahun 2003 Tentang Ketenagakerjaan Bab X Bagian Kedua Pengupahan Pasal 88 Ayat 1 yang menyebutkan "Setiap pekerja/buruh berhak memperoleh penghasilan yang memenuhi penghidupan yang layak bagi kemanusiaan”. Dan Undang-Undang Republik Indonesia No. 13 Tahun 2003 Tentang Ketenagakerjaan Bab X bagian kedua Pengupahan pada Pasal 91 ayat 1 yang menyebutkan "Pengaturan pengupahan yang ditetapkan atas kesepakatan antara pengusaha dan pekerja/buruh atau serikat pekerja/serikat buruh tidak boleh lebih rendah dari ketentuan pengupahan yang ditetapkan peraturan perundang-undangan yang berlaku”.

Rewards mengacu pada semua hal yang dirasakan oleh karyawan sebagai nilai yang dihasilkan dari hubungan kerja dan mencakup semua jenis penghargaan, 
langsung dan tidak langsung serta intrinsik dan ekstrinsik. Komponen khas penghargaan yang membentuk pengungkit dapat digunakan untuk memotivasi, melibatkan dan mempertahankan staff, membayar, memberi manfaat, belajar dan berkembang serta lingkungan kerja (Armstrong, 2006). Cascio (2010) melaporkan bahwa ada tiga perubahan besar dalam filosofi perusahaan mengenai gaji dan tunjangan termasuk peningkatan kesediaan untuk mengurangi ukuran angkatan kerja, untuk melakukan outsourcing pekerjaan dan untuk membatasi bayaran untuk guna mengendalikan biaya upah/gaji dan tunjangan, kurang memperhatikan posisi gaji relatif terhadap pesaing, tetapi dengan apa yang dapat dilakukan perusahaan, dan pelaksanaan program untuk mendorong dan memberi penghargaan atas kinerja, sehingga membuat gaji lebih bervariasi.

Rewards yang diterima karyawan akan membuat mereka merasa dihargai oleh organisasi dan merasa bahwa organisasi serius terlibat dalam pengembangan karir mereka (Dewhurst, 2010). Menurut Hatice (2012) rewards dapat digolongkan menjadi dua jenis, yaitu intrinsic rewards yang dapat berupa nilai positif atau rasa puas karyawan terhadap dirinya sendiri karena telah menyelesaikan suatu tugas yang baginya cukup menantang dan extrinsic rewards yang mencakup kompensasi langsung, kompensasi tidak langsung dan manfaat lainnya. Karyawan memiliki kebutuhan dan persepsi yang berbeda akan rewards, ada karyawan yang menganggap bahwa penghargaan berupa uang sudah cukup untuk memenuhi kebutuhan mereka, sebagian lainnya juga menginginkan penghargaan yang lebih bersifat intrinsik, seperti pemberian peran dalam pengambilan keputusan, tanggung jawab yang lebih besar, kebebasan dan keleluasaan kerja yang lebih besar dengan 
tujuan untuk meningkatkan harga diri dan lain-lain (LaBelle, 2005). Dampak serta persepsi karyawan yang berbeda-beda berkaitan dengan hal ini tidak dapat memungkiri bahwa pada dasarnya kedua jenis rewards tersebut dapat dimanfaatkan secara positif untuk meningkatkan keterlibatan karyawan. Penelitian yang dilakukan oleh Mesepy (2016) ditemukan bahwa rewards berpengaruh positif dan signifikan terhadap keterlibatan karyawan.

Hasil wawancara mengungkapkan bahwa keterlibatan karyawan dalam kegiatan-kegiatan diluar tugas pokok yang diadakan hotel kurang, hal tersebut menunjukkan kurangnya keterlibatan karyawan dalam organisasi. Karyawan yang memiliki tingkat keterlibatan yang tinggi akan memiliki keterlibatan emosi yang tinggi terhadap organisasi sehingga akan berpengaruh dalam menyelesaikan pekerjaan dan cenderung memiliki kualitas kerja yang memuaskan (Schaufeli dan Bakker, 2003). Karyawan yang terlibat adalah orang yang sepenuhnya terserap dan antusias terhadap pekerjaan mereka dan mengambil tindakan positif untuk memajukan reputasi dan kepentingan oraganisasi. Karyawan yang terlibat percaya bahwa mereka dapat membuat perbedaan dalam organisasi tempat mereka bekerja (Sridhar dan Thiruvenkadam, 2014). Keterlibatan karyawan (Employee Engagement) merupakan sikap positif yang dimiliki oleh karyawan terhadap organisasi dan nilai organisasi. Ketika karyawan terlibat dalam pekerjaan mereka, mereka meningkatkan terjadinya perilaku yang mempromosikan fungsi efisien dan efektif organisasi (Cendani dan Endang, 2015). Balakrishnan dan Masthan (2013) menunjukkan bahwa employee engagement dipengaruhi oleh komunikasi internal. 
Hasil wawancara terungkap bahwa interaksi antar antar karyawan rendah dan komunikasi antara atasan dan karyawan kurang, hal tersebut menunjukkan kurangnya komunikasi internal dalam organisasi. Salah satu kunci pencapaian employee engagement adalah adanya komunikasi internal. Komunikasi internal dapat dikatakan sebagai sarana pertukaran informasi dalam organisasi. Pertukaran informasi yang dilakukan oleh pihak manajemen, pemegang saham, dan karyawan yang ada di perusahaan (Adnjani dan Prianti, 2009). Komunikasi internal ini berfokus pada menghubungkan antar individu karyawan, kelompok-kelompok, dan organisasi yang menjadi fasilitator dalam menciptakan kerja sama yang spontan (Balakrishan dan Masthan, 2013). Vercic et al. (2012) menyatakan bahwa pertumbuhan minat terhadap komunikasi internal telah menghasilkan serangkaian penelitian yang bertujuan untuk memahami dan menganalisis lapangan dan menganjurkannya sebagai domain independen. Hayase (2009) pendekatan terhadap komunikasi internal harus menyesuaikan dengan berbagai perubahan yang terjadi di tempat kerja. Dalam mendefinisikan komunikasi internal, Welch dan Jackson (2007) menekankan bahwa ini adalah proses yang melibatkan peserta yaitu manajemen dan karyawan. Dengan demikian, komunikasi internal mengambil arah yang berbeda untuk memastikan bahwa kedua pihak dapat berpartisipasi dalam proses pertukaran informasi.

Tufail et al. (2017) mengatakan rewards berperangaruh secara positif dan signifikan terhadap Organizational Citizenship Behaviour. Selaras dengan itu, Marhamah (2014) mengatakan rewards berperangaruh secara positif dan signifikan terhadap Organizational Citizenship Behaviour, itu berarti bahwa perusahaan 
menerapkan sistem rewards yang baik maka karyawan akan membalasnya dengan Organizational Citizenship Behaviour. Selanjutnya Sinnappan dan Amulraj (2014) mengatakan rewards berperangaruh secara positif dan signifikan terhadap Organizational Citizenship Behaviour. Kemudian penelitian yang dilakukan Alkahtani (2015) menemukan bahwa rewards berpengaruh terhadap Organizational Citizenship Behaviour. Penelitian tersebut juga didukung oleh penelitian yang dilakukan oleh Marinova et al. (2010) yang menyatakan bahwa rewards berpengaruh positif dan signifikan terhadap Organizational Citizenship Behaviour.

$\mathrm{H}_{1}$ : Rewards berpengaruh positif dan signifikan terhadap Organizational Citizenship Behaviour.

Penelitian yang dilakukan oleh Anggraini dkk. (2016) ditemukan bahwa rewards berpengaruh positif dan signifikan terhadap keterlibatan karyawan. Kemudian Penelitian yang dilakukan oleh Mesepy (2016) ditemukan bahwa rewards berpengaruh positif dan signifikan terhadap keterlibatan karyawan, yang berarti ketika perusahaan menerapkan sistem rewards yang baik, maka karyawan akan membalasnya dengan keterlibatan. Selanjutnya penelitian Nusatria (2011) ditemukan rewards berpengaruh positif dan signifikan terhadap employee engagement dan Penelitian yang dilakukan oleh Puspadewi dan Suharnomo (2016) ditemukan bahwa rewards berpengaruh positif dan signifikan terhadap keterlibatan karyawan. Selaras dengan itu penelitian yang dilakukan oleh Koskey dan Sakataka (2015) menunjukkan bahwa rewards berpengaruh positif dan signifikan terhadap Employee Engagement.

$\mathrm{H}_{2}$ : Rewards berpengaruh positif dan signifikan terhadap Keterlibatan Karyawan. 
Penelitian yang dilakukan oleh Sridhar dan Thiruvenkadam (2014) Ditemukan bahwa Employee Engagement memiliki dampak positif yang sangat signifikan terhadap Organizational Citizenship Behavior, itu berarti ketika keterlibatan karyawan di suatu organisasi berada di level yang tinggi, maka akan muncul Organizational Citizenship Behaviour dari pada karyawan. Selanjutnya penelitian yang dilakukan oleh Ariani (2013) hasilnya menunjukkan adanya hubungan positif yang signifikan antara keterlibatan karyawan dan Organizational Citizenship Behaviour Hasil penelitian yang dilakukan oleh Cendani dan Tjahjaningsih (2015) menunjukkan bahwa Employee Engagement berpengaruh positif dan signifikan terhadap Organizational Citizenship Behaviour. Selain itu Hasil penelitian yang dilakukan oleh Kartika dan Muchsinati (2015) menunjukkan bahwa Employee Engagement berpengaruh positif dan signifikan terhadap Organizational Citizenship Behaviour. Selaras dengan itu penelitian yang dilakukan oleh Saradha dan Patrick (2011) menunjukkan bahwa Employee Engagement berpengaruh positif dan signifikan terhadap Organizational Citizenship Behaviour.

$\mathrm{H}_{3}$ : Keterlibatan Karyawan berpengaruh positif dan signifikan terhadap

Penelitian yang dilakukan oleh Amanda (2014) Ditemukan bahwa komunikasi karyawan berpengaruh positif dan signifikan terhadap Organizational Citizenship Behaviour, yang artinya semakin tinggi komunikasi internal dalam organisasi, maka semakin tinggi pula Organizational Citizenship Behaviour. Kemudian penelitian yang dilakukan Rohma (2011) juga menyatakan bahwa komunikasi interpersonal memiliki dampak yang signifikan terhadap 
Organizational Citizenship Behaviour. Selaras dengan itu penelitian yang dilakukan oleh Ayatse dan Ikyanyon (2012) Ditemukan bahwa komunikasi organisasi berpengaruh positif dan signifikan terhadap Organizational Citizenship Behaviour. Selanjutnya Penelitian yang dilakukan oleh Azizah dan Prasetiyowati (2015) Ditemukan bahwa komunikasi berpengaruh positif dan signifikan terhadap Organizational Citizenship Behaviour. Penelitian tersebut juga didukung oleh penelitian yang dilakukan oleh Yildirim (2014) yang menyatakan bahwa komunikasi berpengaruh positif dan signifikan terhadap Organizational Citizenship Behaviour.

$\mathrm{H}_{4}$ : Komunikasi Internal berpengaruh positif dan signifikan terhadap Organizational Citizenship Behaviour

Penelitian yang dilakukan oleh Balakrishnan dan Masthan (2013) Ditemukan bahwa komunikasi internal berpengaruh positif dan signifikan terhadap keterlibatan karyawan, yang berarti jika di dalam organisasi terjadi komunikasi yang baik antara karyawan dengan atasan ataupun sesama karyawan, maka akan muncul kerterlibatan karyawan dalam perusahaan. Kemudian penelitian yang dilakukan Barron et al. (2014) juga menyatakan bahwa komunikasi memiliki dampak yang signifikan terhadap employee engagement. Penelitian yang dilakukan oleh Lorensia dkk. (2015) Ditemukan bahwa komunikasi internal berpengaruh positif dan signifikan terhadap keterlibatan. Selanjutnya Penelitian yang dilakukan oleh Karanges et al. (2015) Ditemukan bahwa komunikasi internal berpengaruh positif dan signifikan terhadap keterlibatan karyawan. Selaras dengan itu penelitian yang dilakukan oleh Oniell et al. (2015) Ditemukan bahwa komunikasi internal berpengaruh positif dan signifikan terhadap keterlibatan karyawan. 
E-Jurnal Manajemen Unud, Vol. 8, No. 3, 2019: 1696 - 1726

$\mathrm{H}_{5}$ : Komunikasi Internal berpengaruh positif dan signifikan terhadap Keterlibatan Karyawan

\section{METODE PENELITIAN}

Lokasi penelitian ini bertempat di Akana Boutique Hotel adalah salah satu hotel berbintang yang terletak di Jalan Sudamala no. 17 Sanur Denpasar. Variabel bebas dalam penelitian ini adalah Rewards (X1) dan Komunikasi Internal (X2). Variabel mediasi dalam penelitian ini adalah Keterlibatan Karyawan (Y1). Variabel terikat dalam penelitian ini adalah Organizational Citizenship Behavior (Y2). Teknik sampel jenuh atau sensus digunakan apabila semua populasi dijadikan sebagai responden, dengan ketentuan bila populasi kurang dari 100 orang (Riduwan dan Sunarto, 2007:17). Seluruh anggota populasi dalam penelitian ini dijadikan responden karena jumlah populasi yang relatif kecil yaitu 50 orang.

Analisis regresi linear sederhana digunakan untuk menjawab permasalahan dalam penelitian ini. Permasalahan yang harus dijawab adalah variabel bebas (rewards, komunikasi internal dan keterlibatan karyawan) berpengaruh secara simultan, secara parsial, dan dominan terhadap variabel terikat organizational citizenship behavior.

\section{HASIL PENELITIAN DAN PEMBAHASAN}

Perhitungan koefisien regresi linier sederhana dalam penelitian ini dilakukan dengan menggunakansoftware SPSS 22.0 for Windows, dan diperoleh hasil yang ditunjukan pada Tabel berikut. 
Tabel 1.

Hasil Uji Regresi Linier Sederhana Struktur 1

\begin{tabular}{lcrrrr}
\hline & \multicolumn{2}{c}{ Unstandardized Coefficients } & $\begin{array}{c}\text { Standardized } \\
\text { Coefficients } \\
\text { Beta }\end{array}$ & t hitung & Sig. uji t \\
\hline (Constant) & 9.948 & 2.296 & & 4.333 & .000 \\
Rewards & .222 & .064 & .448 & 3.470 & .001 \\
\hline Sumber: Data diolah, 2018 & & & &
\end{tabular}

Berdasarkan hasil analisis regresi linier sederhana substruktur 1 seperti yang disajikan pada Tabel 1, maka dapat dibuat persamaan struktural sebagai berikut :

$$
\begin{array}{r}
\mathrm{Y} 2=\beta_{1} \mathrm{X} 1+\mathrm{e}_{2} . \\
\mathrm{Y} 2=0,222 \mathrm{X} 1+\mathrm{e}_{2}
\end{array}
$$

Makna dari koefisien regresi tersebut dijelaskan bahwa nilai koefisien regresi rewards $\left(\mathrm{X}_{1}\right)$ sebesar 0,222 memiliki arti rewards berpengaruh positif terhadap organizational citizenship behavior karyawan Akana Boutique Hotel, bila nilai rewards $\left(\mathrm{X}_{1}\right)$ naik maka nilai dari Organizational Citizenship Behaviour (Y2) akan mengalami peningkatan.

\section{Tabel 2.}

\begin{tabular}{|c|c|c|c|c|c|}
\hline \multirow{2}{*}{ Variabel } & \multicolumn{2}{|c|}{ Unstandardized Coefficients } & \multirow{2}{*}{$\begin{array}{c}\text { Standardized } \\
\text { Coefficients } \\
\text { Beta }\end{array}$} & \multirow{2}{*}{ t hitung } & \multirow{2}{*}{ Sig. uji t } \\
\hline & B & Std. Error & & & \\
\hline (Constant) & 50.630 & 7.609 & & 6.654 & .000 \\
\hline Rewards & .577 & .212 & .366 & 2.724 & .009 \\
\hline
\end{tabular}

Hasil Uji Regresi Linier Sederhana Struktur 2

Sumber: Data diolah, 2018

Berdasarkan hasil analisis regresi linier sederhana substruktur 2 seperti yang disajikan pada Tabel 2, maka dapat dibuat persamaan struktural sebagai berikut:

$$
\begin{aligned}
& \mathrm{Y} 1=\beta_{2} \mathrm{X} 1+\mathrm{e} \ldots \ldots \\
& \mathrm{Y} 1=0,577 \mathrm{X} 1+\mathrm{e}_{1}
\end{aligned}
$$


Makna dari koefisien regresi tersebut dijelaskan bahwa nilai koefisien regresi rewards (X1) sebesar 0,557 memiliki arti berpengaruh positif terhadap keterlibatan karyawan Akana Boutique Hotel, bila nilai rewards (X1) naik maka nilai dari keterlibatan karyawan (Y1) akan mengalami peningkatan

Tabel 3.

Hasil Uji Regresi Linier Sederhana Struktur 3

\begin{tabular}{|c|c|c|c|c|c|}
\hline \multirow{2}{*}{ Variabel } & \multicolumn{2}{|c|}{ Unstandardized Coefficients } & \multirow{2}{*}{$\begin{array}{c}\text { Standardized } \\
\text { Coefficients } \\
\text { Beta }\end{array}$} & \multirow{2}{*}{ t hitung } & \multirow{2}{*}{ Sig. uji t } \\
\hline & B & Std. Error & & & \\
\hline (Constant) & 2.555 & 2.373 & & 1.077 & .287 \\
\hline Keterlibatan Karyawan & .215 & .033 & .683 & 6.481 & .000 \\
\hline
\end{tabular}

Sumber: Data diolah, 2018

Berdasarkan hasil analisis regresi linier sederhana substruktur 3 seperti yang disajikan pada Tabel 3, maka dapat dibuat persamaan struktural sebagai berikut:

$$
\begin{aligned}
& \mathrm{Y} 2=\beta_{3} \mathrm{Y} 1+\mathrm{e}_{2} \ldots \ldots \\
& \mathrm{Y} 2=0,215 \mathrm{Y} 1+\mathrm{e}_{2}
\end{aligned}
$$

Makna dari koefisien regresi tersebut dijelaskan bahwa nilai koefisien regresi keterlibatan karyawan (Y1) sebesar 0,215 memiliki arti keterlibatan karyawan berpengaruh positif terhadap organizational citizenship behavior karyawan akana Akana Boutique Hotel, bila nilai keterlibatan karyawan (Y1) naik maka nilai dari Organizational Citizenship Behaviour (Y2) akan mengalami peningkatan.

Tabel 4. Hasil Uji Regresi Linier Sederhana Struktur 4

\begin{tabular}{lrrrrr}
\hline \multicolumn{1}{c}{ Variabel } & $\begin{array}{c}\text { Unstandardized Coefficients } \\
\text { B }\end{array}$ & $\begin{array}{c}\text { Standardized } \\
\text { Coefficients } \\
\text { Beta }\end{array}$ & t hitung & Sig. uji t \\
\hline (Constant) & .415 & 2.513 & & .165 & .870 \\
Rewards & .113 & .054 & .228 & 2.086 & .042 \\
Keterlibatan Karyawan & .188 & .034 & .600 & 5.476 & .000 \\
\hline
\end{tabular}

Sumber: Data diolah, 2018 
Berdasarkan hasil analisis regresi linier sederhana substruktur 4 seperti yang disajikan pada Tabel 4., maka dapat dibuat persamaan struktural sebagai berikut:

$$
\begin{aligned}
& \mathrm{Y} 2=\beta_{1} \mathrm{X} 1+\beta_{3} \mathrm{Y} 1+\mathrm{e}_{2} \ldots \ldots \ldots \ldots \\
& \mathrm{Y} 2=0,113 \mathrm{X} 1+0,188 \mathrm{Y} 1+\mathrm{e}_{2}
\end{aligned}
$$

Makna dari koefisien regresi tersebut dijelaskan bahwa nilai koefisien regresi rewards $\left(\mathrm{X}_{1}\right)$ sebesar 0,113 memiliki arti rewards berpengaruh positif terhadap organizational citizenship behavior karyawan Akana Boutique Hotel, bila nilai rewards $\left(\mathrm{X}_{1}\right)$ naik maka nilai dari organizational citizenship behavior (Y2) akan mengalami peningkatan.

Nilai koefisien regresi keterlibatan karyawan (Y1) sebesar 0,118 memiliki arti keterlibatan karyawan berpengaruh positif terhadap organizational citizenship behavior karyawan Akana Boutique Hotel, bila nilai keterlibatan karyawan (Y1) naik maka nilai dari Organizational Citizenship Behaviour (Y2) akan mengalami peningkatan.

Tabel 5.

\begin{tabular}{|c|c|c|c|c|c|}
\hline \multirow[t]{2}{*}{ Variabel } & \multicolumn{2}{|c|}{ Unstandardized Coefficients } & \multirow{2}{*}{$\begin{array}{c}\text { Standardized } \\
\text { Coefficients } \\
\text { Beta }\end{array}$} & \multirow[t]{2}{*}{ t hitung } & \multirow[t]{2}{*}{ Sig. uji t } \\
\hline & B & Std. Error & & & \\
\hline (Constant) & -1.140 & 2.753 & & -.414 & .681 \\
\hline Komunikasi Internal & .310 & .045 & .707 & 6.921 & .000 \\
\hline
\end{tabular}
Hasil Uji Regresi Linier Sederhana Struktur 5

Berdasarkan hasil analisis regresi substruktur linier sederhana 5 seperti yang disajikan pada Tabel 5, maka dapat dibuat persamaan struktural sebagai berikut:

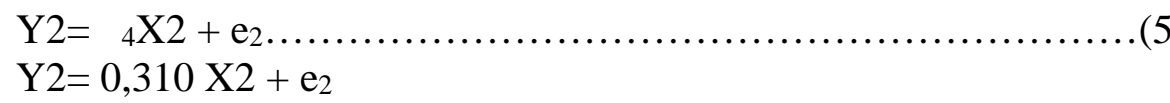

Makna dari koefisien regresi tersebut dijelaskan bahwa nilai koefisien regresi Komunikasi internal (X2) sebesar 0,310 memiliki arti Komunikasi internal 
berpengaruh positif terhadap organizational citizenship behavior karyawan Akana Boutique Hotel, bila nilai komunikasi internal (X2) naik maka nilai dari Organizational Citizenship Behaviour (Y2) akan mengalami peningkatan.

\section{Tabel 6.}

Hasil Uji Regresi Linier Sederhana Struktur 6

\begin{tabular}{|c|c|c|c|c|c|}
\hline \multirow[t]{2}{*}{ Variabel } & \multicolumn{2}{|c|}{ Unstandardized Coefficients } & \multirow{2}{*}{$\begin{array}{c}\text { Standardized } \\
\text { Coefficients } \\
\text { Beta }\end{array}$} & \multirow[t]{2}{*}{ t hitung } & \multirow[t]{2}{*}{ Sig. uji t } \\
\hline & B & Std. Error & & & \\
\hline (Constant) & 21.677 & 10.107 & & 2.145 & .037 \\
\hline Komunikasi Internal & .808 & .164 & .579 & 4.916 & .000 \\
\hline
\end{tabular}

Berdasarkan hasil analisis regresi linier sederhana substruktur 6 seperti yang disajikan pada Tabel 6 , maka dapat dibuat persamaan struktural sebagai berikut:

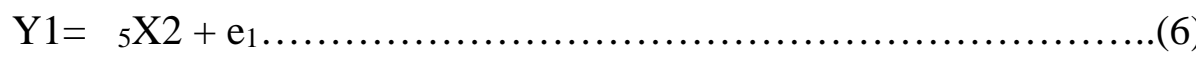

$$
\begin{aligned}
& \mathrm{Y} 1=0,808 \mathrm{X} 2+\mathrm{e}_{1}
\end{aligned}
$$

Makna dari koefisien regresi tersebut dijelaskan bahwa nilai koefisien regresi Komunikasi internal (X2) sebesar 0,808 memiliki arti Komunikasi internal berpengaruh positif terhadap Keterlibatan karyawan Akana Boutique Hotel, bila nilai komunikasi internal (X2) naik maka nilai dari Keterlibatan karyawan (Y1) akan mengalami peningkatan.

Tabel 7.

Hasil Uji Regresi Linier Sederhana Struktur 7

\begin{tabular}{|c|c|c|c|c|c|}
\hline \multirow{2}{*}{ Variabel } & \multicolumn{2}{|c|}{ Unstandardized Coefficients } & \multirow{2}{*}{$\begin{array}{c}\text { Standardized } \\
\text { Coefficients } \\
\text { Beta }\end{array}$} & \multirow{2}{*}{ t hitung } & \multirow{2}{*}{ Sig. uji t } \\
\hline & B & Std. Error & & & \\
\hline (Constant) & -3.946 & 2.563 & & -1.539 & .130 \\
\hline Komunikasi Internal & .205 & .049 & .468 & 4.205 & .000 \\
\hline Keterlibatan Karyawan & .129 & .035 & .412 & 3.702 & .001 \\
\hline
\end{tabular}


Berdasarkan hasil analisis regresi linier sederhana substruktur 7 seperti yang disajikan pada Tabel 7, maka dapat dibuat persamaan struktural sebagai berikut:

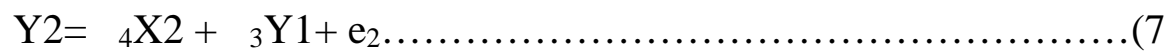

$$
\begin{aligned}
& \mathrm{Y} 2=0,205 \mathrm{X} 2+0,129 \mathrm{Y} 1+\mathrm{e}_{2}
\end{aligned}
$$

Makna dari koefisien regresi tersebut dijelaskan bahwa nilai koefisien regresi Komunikasi internal (X2) sebesar 0,205 memiliki arti Komunikasi internal berpengaruh positif terhadap organizational citizenship behavior karyawan Akana Boutique Hotel, bila nilai komunikasi internal (X2) naik maka nilai dari Organizational Citizenship Behaviour (Y2) akan mengalami peningkatan. Nilai koefisien regresi keterlibatan karyawan (Y1) sebesar 0,129 memiliki arti keterlibatan karyawan berpengaruh positif terhadap organizational citizenship behavior karyawan Akana Boutique Hotel, bila nilai keterlibatan karyawan (Y1) naik maka nilai dari Organizational Citizenship Behaviour (Y2) akan mengalami peningkatan.

Tabel 8 menunjukkan persamaan regersi hubungan Rewards dengan Organizational Citizenship Behaviour yang ditunjukkan oleh nilai determinasi (Adjusted $R$ Square) sebesar 0,184 mempunyai arti bahwa sebesar 18,4\% variasi Organizational Citizenship Behaviourdipengaruhi oleh variasi rewards, sedangkan sisanya sebesar $81,6 \%$ dijelaskan oleh faktor lain yang tidak dimasukkan ke dalam model. Nilai P pada persamaan regresi hubungan Rewards dengan Organizational Citizenship Behaviour sebesar 0,001 yang lebih kecil dari $\alpha=0,05$, ini berarti model yang digunakan pada penelitian ini adalah layak. Berdasarkan persamaan regresi 
hubungan Rewards dengan Organizational Citizenship Behaviour nilai signifikansi uji t sebesar 0,001, maka $\mathrm{H}_{0}$ ditolak. Hasil ini mendukung hipotesis $\mathrm{H}_{1}$ yang menyatakan rewards berpengaruh positif terhadap organizational citizenship behavior pada Akana Boutique Hotel.

Tabel 8.

Uji Kelayakan Model dan Uji Hipotesis Model 1

\begin{tabular}{|c|c|c|c|c|c|c|}
\hline Struktur & $\begin{array}{l}\text { Persamaan } \\
\text { Regresi }\end{array}$ & $\begin{array}{l}\text { Hubungan } \\
\text { Antar Variabel }\end{array}$ & Sign. T & B & $\begin{array}{l}\text { Adjusted } \\
R \text { Square }\end{array}$ & $\mathbf{P}$ \\
\hline 1 & $\begin{array}{c}\mathrm{Y} 2=\underset{\mathrm{e}_{1}}{\beta_{1} \mathrm{X} 1+} \\
\mathrm{e}_{1}\end{array}$ & $\begin{array}{l}\text { Rewards } \rightarrow \\
\text { Organizational } \\
\text { Citizenship } \\
\text { Behaviour }\end{array}$ & 0.001 & 0.222 & 0,184 & 0.001 \\
\hline 2 & $\begin{array}{c}\mathrm{Y} 1=\underset{\mathrm{e}_{2}}{\beta_{2} \mathrm{X} 1+}\end{array}$ & $\begin{array}{l}\text { Rewards } \rightarrow \\
\text { Keterlibatan } \\
\text { Karyawan }\end{array}$ & 0.009 & 0.577 & 0,116 & 0.009 \\
\hline 3 & $\begin{array}{c}\mathrm{Y} 2=\beta_{3} \mathrm{Y} 1+ \\
\mathrm{e}_{1}\end{array}$ & $\begin{array}{l}\text { Keterlibatan } \\
\text { Karyawan } \rightarrow \\
\text { Organizational } \\
\text { Citizenship } \\
\text { Behaviour }\end{array}$ & 0.000 & 0.215 & 0,456 & 0.000 \\
\hline \multirow[t]{2}{*}{4} & & $\begin{array}{l}\text { Rewards } \rightarrow \\
\text { Organizational } \\
\text { Citizenship } \\
\text { Behaviour }\end{array}$ & 0.042 & 0.113 & 0,491 & 0.042 \\
\hline & $\begin{array}{c}\mathrm{Y} 2=\beta_{1} \mathrm{X} 1+ \\
\beta_{3} \mathrm{Y} 1+\mathrm{e}_{1}\end{array}$ & $\begin{array}{l}\text { Keterlibatan } \\
\text { Karyawan } \rightarrow \\
\text { Organizational } \\
\text { Citizenship } \\
\text { Behaviour }\end{array}$ & 0.000 & 0.188 & & 0.000 \\
\hline
\end{tabular}

Sumber: Data diolah, 2018

Tabel 8 menunjukkan persamaan regersi hubungan Rewards dengan Keterlibatan Karyawan yang ditunjukkan oleh nilai determinasi (Adjusted $R$ Square) sebesar 0,116 mempunyai arti bahwa sebesar 11,6\% variasi Keterlibatan Karyawan dipengaruhi oleh variasi rewards, sedangkan sisanya sebesar 88,4\% dijelaskan oleh faktor lain yang tidak dimasukkan ke dalam model. Nilai P pada persamaan regresi hubungan Rewards dengan Keterlibatan Karyawan sebesar 
0,009 yang lebih kecil dari $\alpha=0,05$, ini berarti model yang digunakan pada penelitian ini adalah layak. Berdasarkan persamaan regresi hubungan Rewards dengan Keterlibatan Karyawannilai signifikansi uji t sebesar 0,009, maka $\mathrm{H}_{0}$ ditolak. Hasil ini mendukung hipotesis $\mathrm{H}_{1}$ yang menyatakan rewards berpengaruh positif terhadap Keterlibatan Karyawan pada Akana Boutique Hotel.

Tabel 8 menunjukkan persamaan regersi hubungan Keterlibatan Karyawan dengan Organizational Citizenship Behaviour yang ditunjukkan oleh nilai determinasi (Adjusted $R$ Square) sebesar 0,456 mempunyai arti bahwa sebesar 45,6\% variasi Organizational Citizenship Behaviour dipengaruhi oleh variasi Keterlibatan Karyawan sedangkan sisanya sebesar 54,4\% dijelaskan oleh faktor lain yang tidak dimasukkan ke dalam model. Nilai $\mathrm{P}$ pada persamaan regresi hubungan Rewards dengan Organizational Citizenship Behaviour sebesar 0,000 yang lebih kecil dari $\alpha=0,05$, ini berarti model yang digunakan pada penelitian ini adalah layak. Berdasarkan persamaan regresi hubungan Keterlibatan Karyawan dengan Organizational Citizenship Behaviour nilai signifikansi uji t sebesar 0,000, maka $\mathrm{H}_{0}$ ditolak. Hasil ini mendukung hipotesis $\mathrm{H}_{1}$ yang menyatakan Keterlibatan Karyawan berpengaruh positif terhadap organizational citizenship behavior pada Akana Boutique Hotel.

Tabel 8 struktur 4 menunjukkan persamaan regersi hubungan Rewards dan Keterlibatan Karyawan dengan Organizational Citizenship Behaviour yang ditunjukkan oleh nilai determinasi (Adjusted $R$ Square) sebesar 0,491 mempunyai arti bahwa sebesar 49,1\% variasi Organizational Citizenship Behaviour dipengaruhi oleh variasi Rewards dan Keterlibatan Karyawan sedangkan sisanya 
sebesar 50,9\% dijelaskan oleh faktor lain yang tidak dimasukkan ke dalam model. Nilai P pada persamaan regresi hubungan Rewards dengan Organizational Citizenship Behaviour sebesar 0,042 yang lebih kecil dari $\alpha=0,05$, ini berarti model yang digunakan pada penelitian ini adalah layak. Nilai P pada persamaan regresi hubungan Keterlibatan KaryawandenganOrganizational Citizenship Behaviour sebesar 0,000 yang lebih kecil dari $\alpha=0,05$, ini berarti model yang digunakan pada penelitian ini adalah layak.Berdasarkan persamaan regresi hubungan Rewards dengan Organizational Citizenship Behaviour nilai signifikansi uji t sebesar 0,042, maka $\mathrm{H}_{0}$ ditolak. Hasil ini mendukung hipotesis $\mathrm{H}_{1}$ yang menyatakan rewards berpengaruh positif terhadap organizational citizenship behavior pada Akana Boutique Hotel. Berdasarkan persamaan regresi hubungan Keterlibatan Karyawan dengan Organizational Citizenship Behaviour nilai signifikansi uji t sebesar 0,000, maka $\mathrm{H}_{0}$ ditolak. Hasil ini mendukung hipotesis $\mathrm{H}_{1}$ yang menyatakan rewards berpengaruh positif terhadap organizational citizenship behavior pada Akana Boutique Hotel.

Tabel 9 menunjukkan persamaan regersi hubungan Keterlibatan Karyawan dengan Organizational Citizenship Behaviour yang ditunjukkan oleh nilai determinasi (Adjusted $R$ Square) sebesar 0,456 mempunyai arti bahwa sebesar 45,6\% variasi Organizational Citizenship Behaviour dipengaruhi oleh variasi Keterlibatan Karyawan sedangkan sisanya sebesar 54,4\% dijelaskan oleh faktor lain yang tidak dimasukkan ke dalam model. Nilai $\mathrm{P}$ pada persamaan regresi hubungan Rewards dengan Organizational Citizenship Behaviour sebesar 0,000 yang lebih kecil dari $\alpha=0,05$, ini berarti model yang digunakan pada penelitian ini 
adalah layak. Berdasarkan persamaan regresi hubungan Keterlibatan Karyawan dengan Organizational Citizenship Behaviour nilai signifikansi uji t sebesar 0,000, maka $\mathrm{H}_{0}$ ditolak.Hasil ini mendukung hipotesis $\mathrm{H}_{1}$ yang menyatakan Keterlibatan Karyawan berpengaruh positif terhadap organizational citizenship behavior pada Akana Boutique Hotel.

Tabel 9.

Uji Kelayakan Model dan Uji Hipotesis Model 2

\begin{tabular}{|c|c|c|c|c|c|c|}
\hline Struktur & $\begin{array}{l}\text { Persamaan } \\
\text { Regresi }\end{array}$ & $\begin{array}{l}\text { Hubungan Antar } \\
\text { Variabel }\end{array}$ & Sign. $t$ & B & $\begin{array}{l}\text { Adjusted } \\
R \text { Square }\end{array}$ & $\mathbf{P}$ \\
\hline 3 & $\mathrm{Y} 2=\beta_{3} \mathrm{Y} 1+\mathrm{e}_{1}$ & $\begin{array}{l}\text { Keterlibatan } \\
\text { Karyawan } \\
\text { Organizational } \\
\text { Citizenship } \\
\text { Behaviour }\end{array}$ & 0.000 & 0.215 & 0,456 & 0.000 \\
\hline 5 & $\mathrm{Y} 2=\beta 4 \mathrm{X} 2+\mathrm{e} 1$ & $\begin{array}{l}\text { Komunikasi Internal } \\
\rightarrow \quad \text { Organizational } \\
\text { Citizenship } \\
\text { Behaviour }\end{array}$ & 0.000 & 0.310 & 0,489 & 0.000 \\
\hline 6 & $\mathrm{Y} 1=\beta 5 \mathrm{X} 2+\mathrm{e} 2$ & $\begin{array}{l}\text { Komunikasi } \text { Internal } \\
\rightarrow \quad \text { Keterlibatan } \\
\text { Karyawan }\end{array}$ & 0.000 & 0.808 & 0,321 & 0.000 \\
\hline \multirow[t]{2}{*}{7} & $\begin{array}{l}\mathrm{Y} 2=\beta 4 \mathrm{X} 2+ \\
\beta 3 \mathrm{Y} 1+\mathrm{e} 1\end{array}$ & $\begin{array}{l}\text { Komunikasi Internal } \\
\rightarrow \quad \text { Organizational } \\
\text { Citizenship } \\
\text { Behaviour }\end{array}$ & 0.000 & 0.205 & 0,596 & 0.000 \\
\hline & & $\begin{array}{l}\text { Keterlibatan } \\
\text { Karyawan } \\
\text { Organizational } \\
\text { Citizenship } \\
\text { Behaviour }\end{array}$ & 0.0001 & 0.129 & & 0.0001 \\
\hline
\end{tabular}

Sumber: Data diolah, 2018

Tabel 9 menunjukkan persamaan regresi hubungan Komunikasi Internal dengan Organizational Citizenship Behaviouryang ditunjukkan oleh nilai determinasi (Adjusted $R$ Square) sebesar 0,489 mempunyai arti bahwa sebesar 46,7\% variasi Organizational Citizenship Behaviour dipengaruhi oleh variasi Komunikasi Internal sedangkan sisanya sebesar 51,1\% dijelaskan oleh faktor lain 
yang tidak dimasukkan ke dalam model. Nilai P pada persamaan regresi hubungan Komunikasi Internal dengan Organizational Citizenship Behaviour sebesar 0,000 yang lebih kecil dari $\alpha=0,05$, ini berarti model yang digunakan pada penelitian ini adalah layak. Berdasarkan persamaan regresi hubungan Komunikasi Internal dengan Organizational Citizenship Behaviour nilai signifikansi uji t sebesar 0,000, maka $\mathrm{H}_{0}$ ditolak.Hasil ini mendukung hipotesis $\mathrm{H}_{1}$ yang menyatakan Komunikasi Internal berpengaruh positif terhadap organizational citizenship behavior pada Akana Boutique Hotel.

Tabel 9 menunjukkan persamaan regersi hubungan Komunikasi Internal dengan Keterlibatan Karyawan yang ditunjukkan oleh nilai determinasi (Adjusted $R$ Square) sebesar 0,321 mempunyai arti bahwa sebesar 32,1\% variasi Keterlibatan Karyawan dipengaruhi oleh variasi Komunikasi Internal, sedangkan sisanya sebesar 67,9\% dijelaskan oleh faktor lain yang tidak dimasukkan ke dalam model. Nilai P pada persamaan regresi hubungan Komunikasi Internal dengan Keterlibatan Karyawan sebesar 0,000 yang lebih kecil dari $\alpha=0,05$, ini berarti model yang digunakan pada penelitian ini adalah layak. Berdasarkan persamaan regresi hubungan Komunikasi Internal dengan Keterlibatan Karyawan nilai signifikansi uji t sebesar 0,009, maka $\mathrm{H}_{0}$ ditolak. Hasil ini mendukung hipotesis $\mathrm{H}_{1}$ yang menyatakan Komunikasi Internal berpengaruh positif terhadap Keterlibatan Karyawan pada Akana Boutique Hotel.

Tabel 9 struktur 7 menunjukkan persamaan regersi hubungan Komunikasi Internaldan Keterlibatan Karyawan dengan Organizational Citizenship Behaviour yang ditunjukkan oleh nilai determinasi (Adjusted $R$ Square) sebesar 0,596 
mempunyai arti bahwa sebesar $59,6 \%$ variasi Organizational Citizenship Behaviour dipengaruhi oleh variasi Komunikasi Internal dan Keterlibatan Karyawan sedangkan sisanya sebesar 50,9\% dijelaskan oleh faktor lain yang tidak dimasukkan ke dalam model. Nilai $\mathrm{P}$ pada persamaan regresi hubungan Komunikasi Internal dengan Organizational Citizenship Behaviour sebesar 0,000 yang lebih kecil dari $\alpha=0,05$, ini berarti model yang digunakan pada penelitian ini adalah layak. Nilai P pada persamaan regresi hubungan Keterlibatan Karyawan dengan Organizational Citizenship Behaviour sebesar 0,001 yang lebih kecil dari $\alpha$ $=0,05$, ini berarti model yang digunakan pada penelitian ini adalah layak Berdasarkan persamaan regresi hubungan Komunikasi Internal dengan Organizational Citizenship Behaviour nilai signifikansi uji t sebesar 0,000, maka $\mathrm{H}_{0}$ ditolak. Hasil ini mendukung hipotesis $\mathrm{H}_{1}$ yang menyatakan Komunikasi Internal berpengaruh positif terhadap organizational citizenship behavior pada Akana Boutique Hotel. Berdasarkan persamaan regresi hubungan Keterlibatan Karyawan dengan Organizational Citizenship Behaviour nilai signifikansi uji t sebesar 0,001 , maka $\mathrm{H}_{0}$ ditolak. Hasil ini mendukung hipotesis $\mathrm{H}_{1}$ yang menyatakan rewards berpengaruh positif terhadap organizational citizenship behavior pada akana boutique hotel.

Pengujian pengaruh tidak langsung variabel reawrds (X1) terhadap variabel Organizational Citizenship Behaviour $\left(\mathrm{Y}_{2}\right)$ dilakukan dengan uji sobel. Untuk menguji signifikansi pengaruh tidak langsung maka menghitung nilai $\quad \mathrm{z} \quad$ dari koefisien ab dengan rumus sebagai berikut :

$$
Z=\frac{b 1 b 3}{S 1 b 3}
$$




$$
\begin{aligned}
& Z=\frac{(0,2)(0,2)}{0,0} \\
& Z=3,0341 \text { dengan signifikansi } 0,00024
\end{aligned}
$$

Oleh karena Z hitung sebesar 3,0341> 1,96. Artinya Keterlibatan karyawan $\left(\mathrm{Y}_{1}\right)$ merupakan variabel yang memediasi rewards (X1) terhadap Organizational Citizenship Behaviour $\left(\mathrm{Y}_{2}\right)$ atau dengan kata lain rewards berpengaruh secara tidak langsung terhadap Organizational Citizenship Behaviourmelalui keterlibatan karyawan.

Pengujian pengaruh tidak langsung variabel komunikasi internal (X2) terhadap variabel Organizational Citizenship Behaviour $\left(\mathrm{Y}_{2}\right)$ dilakukan dengan uji sobel. Untuk menguji signifikansi pengaruh tidak langsung maka menghitung nilai $\mathrm{z}$ dari koefisien ab dengan rumus sebagai berikut :

$$
\begin{aligned}
& Z=\frac{b 1 b 3}{S 1 b 3} \ldots \ldots \ldots \ldots \ldots \ldots \ldots \ldots \ldots \ldots \ldots \ldots \ldots \ldots \ldots \\
& Z=\frac{(0,3)(0,2)}{0,0} \\
& Z=4,7074 \text { dengan signifikansi } 0,000
\end{aligned}
$$

Oleh karena Z hitung sebesar 4,7074> 1,96. Artinya Keterlibatan karyawan (Y) merupakan variabel yang memediasi komunikasi internal (X2) terhadap Organizational Citizenship Behaviour $\left(\mathrm{Y}_{2}\right)$ atau dengan kata lain komunikasi internal berpengaruh secara tidak langsung terhadap Organizational Citizenship Behaviourmelalui keterlibatan karyawan.

Hasil dari penelitian ini menunjukkan bahwa rewards dan komunikasi internal berpengaruh positif dan signifikan terhadap keterlibatan, sementara itu juga rewards, komunikasi internal dan keterlibatan karyawan berpengaruh positif dan 
signifikan terhadap Organizational Citizenship Behaviour pada Akana Boutique Hotel. Dari hasil ini, owner, Manager, serta pengelola Akana Boutique Hotel sebaiknya terus meningkatkan pemberian rewards pada karyawan serta meningkatkan komunikasi internal yang telah terbentuk dengan baik karena telah terbukti bahwa keduanya telah mempengaruhi keterlibatan karyawan pada pekerjaan terkait tugas pokok maupun pada masalah lainnya yang terjadi pada perusahaan yang berakibat kemajuan pada perusahaan. Kebijakan pengupahan pada tingkat jabatan terrendah seharusnya sesuai dengan harapan karyawan yang selaras dengan ketentuan UU No.13 Tahun 2003 pasal 88 Ayat 1 yang menyebutkan bahwa "Setiap Pekerja atau Buruh berhak memperoleh penghasilan yang memenuhi penghidupan yang layak bagi kemanusiaan" karena masih adanya temuan dalam perusahaan bahwa gaji karyawan yang diterima tidak sesuai dengan harapan karyawan. Sosialisasi formula perhitungan penggajian diperlukan, agar karyawan merasa diperlakukan dengan adil. Karena karyawan Akana Boutique Hotel faktanya belum mengetahui apakah gaji yang diterima dibandingkan pengorbanan yang telah dilakukan sebanding dengan gaji yang diterima rekan kerja dibandingkan dengan pengorbanan yang rekan kerja lakukan. Dari sisi konumikasi internal, temuan yang ada menunjukkan masih ada keadaan dimana karyawan tidak dapat menyampaikan aspirasinya, masukan atau saran bawahan tidak ditindak lanjuti oleh atasan, dan masih adanya karyawan yang tidak diijinkan mengajukan masukan atau saran kepada atasan. Terlebih lagi pada penelitian ini menunjukkan hasil bahwa rewards yang di berikan, komunikasi internal yang terjalin dalam perusahaan dengan baik, dan keterlibatan karyawan yang maksimal memang benar mempengaruhi prilaku 
Organizational Citizenship Behaviour pada karyawan. Sesuai dengan temuan faktor yang mempengaruhi prilaku Organizational Citizenship Behaviour, dalam penelitian ini juga menemukan prilaku karyawan yang tidak bersedia menggantikan rekan kerja lain ketika sedang berhalangan dan masih adanya karyawan yang tidak membantu rekan kerja ketika beban pekerjaannya masih tersisa. Apabila hal ini terus berkembang dalam pemikiran karyawan maka temuan ini akan menurunkan tingkat keterlibatan karyawan terhadap masalah maupun jobdesk masing-masing unit di dalam perusahaan. Peningkatan pada indikator-indikator dalam penelitian diharapkan juga akan merubah sikap beberapa karyawan yang masih merasa kurang puas dengan contohnya seperti upah serta rewards yang di berikan perusahaan. Karena apabila masih terdapat karyawan yang masih merasa kurang puas tentu akan berpengaruh pada indikator lainnya, tak hanya itu sikap tersebut juga tentu kedepannya akan memengaruhi kepedulian karyawan lain pada perusahaan sehingga menurunkan kualitas Hotel.

Terdapat keterbatasan yang mempengaruhi kondisi dari penelitian yang dilakukan. Adapun keterbatasan dalam penelitian ini yaitu jumlah responden hanya 50 orang karyawan dan hanya dari lingkungan Akana Boutique Hotel, sehingga hasil penelitian ini hanya dapat diterapkan dilingkungan kerja Akana Boutique Hotel dan tidak dapat digeneralisasi pada lingkungan perusahaan lain.

Data Organizational Citizenship Behaviour tidak diukur dengan seksama karena hanya menggunakan pengujian pada level dimensi, sementara penelitian terdahulu menggunakan menggunakan data Organizational Citizenship Behaviour 
dengan 16 indikator yang neliputi 5 dimensi Organizational Citizenship Behaviouryaitu altruism, conscientiousness, courtesy, civic vurtue, sportsmanship. SIMPULAN DAN SARAN

Berdasarkan tujuan penelitian, rumusan masalah dan hasil penelitian dengan pembahasan yang telah dipaparkan, maka dapat diambil kesimpulan dari penelitian ini adalah Rewards berpengaruh positif dan signifikan terhadap Organizational Citizenship Behaviour. Semakin tinggi rewards yang diberikan, semakin tinggi Organizational Citizenship Behaviour karyawan Akana Boutique Hotel.

Rewards berpengaruh positif dan signifikan terhadap keterlibatan karyawan. Semakin tinggi rewards yang diberikan, semakin tinggi keterlibatan karyawan Akana Boutique Hotel. Keterlibatan Karyawan berpengaruh positif dan signifikan terhadap Organizational Citizenship Behaviour. Semakin tinggi keterlibatan karyawan, semakin tinggi Organizational Citizenship Behaviour karyawan Akana Boutique Hotel. Komunikasi internal berpengaruh positif dan signifikan terhadap Organizational Citizenship Behaviour. Semakin tinggi komunikasi internal, semakin tinggi Organizational Citizenship Behaviour karyawan Akana Boutique Hotel. Komunikasi internal berpengaruh positif dan signifikan terhadap keterlibatan karyawan. Semakin tinggi komunikasi internal, semakin tinggi keterlibatan karyawan Akana Boutique Hotel. Keterlibatan karyawan memediasi hubungan rewards dan komunikasi internal terhadap Organizational Citizenship Behaviour.

Berdasarkan hasil penelitian dan kesimpulan, maka saran-saran yang dapat diberikan adalah saran bagi pihak pengelola Akana Boutique Hotel yakni yang 
pertama untuk dapat meningkatkan kebijakan-kebijakan terkait pemberian upah dan pekerjaan tambahan yang dikerjakan oleh karyawan, diberi imbalan yang sesuai dengan ketentuan pengupahan, mensosialisasikan formula perhitungan penggajian dan upah lembur agar karyawan merasa diperlakukan secara adil.

Peningkatan komunikasi internal, baik komunikasi internal kebawah terkait informasi dari atasan, komunikasi keatas terkait laporan tugas pokok masingmasing bidang maupun komunikasi mendatar antar karyawan. pihak pengelola memberikan kesempatan karyawan untuk menyampaikan aspirasi, masukan dan saran yang membangun demi kemajuan perusahaan melalui monthly meeting yang di lakukan tiap unit kemudian dari pihak kepala unit yang akan menyampaikan aspirasi tersebut sesuai dengan alur koordinasi. Apabila komunikasi internal terjalin dengan baik tentu akan menyelesaikan berbagai pekerjaan ataupun masalah sesulit apapun karena komunikasi yang baik.

Terdapat temuan bahwa masih seringnya karyawan menggantikan pekerjaan dari karyawan lain, saran untuk pengelola agar dapat menambah karyawan baru agar hal ini tidak sering terjadi dan dengan penambahan karyawan akan menunjukkan bahwa Akana Boutique Hotel semakin maju karena organisasi dalam perusaahaan tersebut semakin besar.

Saran bagi pihak karyawan Akana Boutique Hotel yakni apabila telah adanya kebijakan pemberian hak yang memang sesuai dengan apa yang menjadi tugas pokok, maka sebaiknya sebagai karyawan yang baik harus menjalankan kewajiban pekerjaan dengan selalu terlibat dengan pekerjaan yang ada (keterlibatan karyawan). Selain itu juga sebagai karyawan yang baik alangkah baiknya dan akan 
lebih dapat memajukan perusahaan apabila tumbuhnya prilaku Organizational Citizenship Behaviour dalam diri apabila tugas pokok kita telah terpenuhi. Tumbuhnya prilaku Organizational Citizenship Behaviourakan meringankan beban perusahaan yang nantinya akan berdampak positif pada kemajuan perusahan. Apabila kemajuan perusahaan positif tentu akan berdampak pada upah dan juga rewards yang akan karyawan terima pula.

Saran bagi penelitian selanjutnya, penelitian ini hanya sebatas meneliti mengenai efek mediasi keterlibatan karyawan pada hubungan rewardsdan komunikasi internal dengan organizational citizenship behaviour. Peneliti selanjutnya diharapkan untuk menambah variable lain karena peneliti ini hanya memandang keterlibatan karyawan sebagai mediasi hubungan rewards dan komunikasi internal dengan organizational citizenship behaviour. Peneliti selanjutnya juga diharapkan untuk dapat mengambil sampel diluar lingkungan industry jasa perhotelan atau villa serta menggunakan variable lain sebagai alat analisisnya.

\section{REFERENSI}

Adnjani , M. D dan Prianti, D. D. (2009). Internal Communication Towards Employee Engagement Inside Sultan Agung Islamic University (UNINSULA).Jurnal Ilmiah Komunikasi (Makna),1(1), hal. 1-14.

Alkahtani, Ali. (2015). Organizational Citizenship Behavior (OCB) and Rewards. International Business Research, 8(4). Pp. 210-222

Amanda, A. R. (2014). Pengaruh Employee Communication Terhadap Organizatational Citizenship Behavior yang Dimediasi Oleh Employee Engagement Pada Karyawan di Beberapa Fakultas Trisakti Jakarta.Jurnal Manajemen Dan Pemasaran Jasa,5(12), Hal: 102-109

Anggraini, Lia. Astuti, Endang Siti Dan Prasetya, Arik. (2016). Faktor-Faktor Yang Mempengaruhi Employee Engagement Generasi Y (Studi Pada Karyawan 
Pt Unilever Indonesia Tbk-Surabaya). Jurnal Administrasi Bisnis,37(2), Hal: 183-191.

Ariani, D. W. (2013). The Relationship Between Employee Engagement, Organizational Citizenship Behavior, And Counterproductive Work Behavior. International Journal Of Business Administration,4,(2). Pp: 4656.

Armstrong, M. (2006).A Hand Book of Human Resource Management Practice10th edition.London: Kogan Page.

Ayatse, F. A. and Ikyanyo.(2012). Organizational Communication, Job Stress And Citizenship Behavior Of It Employee In Nigerian Universities. Journal Of Business Administration Reseacch,1(1). Pp: 46-56.

Azizah, Siti Nur. Prasetiyowati, Elly. (2015). Pengaruh Komunikasi Organisasi, Komitmen Organisasi Dan Kepuasan Kerja Terhadap Organizational Citizenship Behavior Di Bagian Umum Kantor Sekretariat Daerah Kabupaten Kebumen. Jurnal Bisnis Dan Manajemen (JBIMA),3(2). Hal. $122-132$

Balakrishnan, C. and Masthan, D. (2013). Impact Of Internal Communication On Employee Engagement-A Study At Delhi International Airport. International Journal Of Scientific And Research Publications,3(8), Pp: 113.

Barron, P., Leask, A., and Fyall, A. (2014). Engaging The Multi-Generational Workforce In Tourism And Hospitality. Tourism Review, 69(4), Pp: 245263.

Cascio, W. F. (2010). Managing Human Resources. Colorado: Mc Graw -Hill.

Cendani, Citta. Dan Tjahjaningsih, Endang. (2015). Pengaruh Employee Engagement Dan Modal Sosial Terhadap Kinerja Karyawan Dengan Ocb (Organizational Citizenship Behaviour) Sebagai Mediasi (Studi Pada Bank Jateng Kantor Pusat ). Media Ekonomi Dan Manajemen, 30(2), Hal: 149160.

Dewhurst, M. (2010). Motivating people: getting beyond money, Business Source Complete.

Firdaus, Fathan. (2010). Pengaruh Iklim Psikologis Karyawan terhadap Kinerja Karyawan dengan Organizational Citizenship Behaviour (OCB) dan Kepuasan Kerja Karyawan sebagai variabel mediasi studi pada PT. Eindstred-KBN Jakarta.Skripsi, Sarjana Jurusan Ekonomi Manajemen pada Universitas Sebelas Maret, Surakarta.

Garay, Hannah Dara Vanzuela. (2006). Kinerja Extra-Role dan Kebijakan Kompensasi.Sinergi, Kajian Bisnis dan Manajemen, 8(1), hal: 33-42. 
Graham, MD and Manus, TM. (2002). Creating a Total Rewards Strategy: A toolk it

Hatice, O. (2012). The Influence of Intrinsic and Extrinsic Rewards on Employee Results: An Empirical Analysis in Turkish Manufacturing Industry. Business and Economic researchJournal,3(3).Pp :23-40

Hayase, L.K.T. (2009), Internal Communication in Organizations and Employee Engagement.Thesis, University of Nevada, Las Vegas.

Karanges, Emma. Johnston, Kim. Beatson, Amanda. and Lings, Ian. (2015). The Influence Of Internal Communication On Employee Engagement: A Pilot Study. Public Relations Review,4(1), Pp: 129-131.

Kartika, Jenetha. Dan Muchsinati, Evi Silvana. (2015). Analisis Faktor-Faktor Yang Mempengaruhi Organizational Citizenship Behavior Pada Karyawan Bpr Di Batam.Jurnal Manajemen, 14(2), Hal: 245-270.

Koskey, A. K. and Sakataka, W. (2015).Effect of reward on employee engagement and commitment at Rift Valley Bottlers Company.International Academic Journal of Human Resource and Business Administration, 1 (5), Pp. 36-54

Lorensia, Ines Margaretha. Ngo, Diana Kartika dan Widjaja, Debora. (2015).Analisa Pengaruh Komunikasi Internal, Intrinsic Rewards Dan Recognition Terhadap Employee Engagement Di Surabaya Suite Hotel. Jurnal Hospitality dan Manajemen Jasa,.3(2), Hal: 502-517.

Marhamah. (2014). Pengaruh Quality Of Work Life (Qwl) Dan Reward Terhadap Organizational Citizenship Behavior (Ocb) Pada Guru Sekolah Dasar Negeri (Sdn) Di Babelan Bekasi. Jurnal Manajemen Pendidikan, 5(2). Hal: 937-947.

Marinova, Sophia V. Henry Moon. and Linn Van Dyne. (2010). Are all good soldier behaviors the same? Supporting multidimensionality of organizational citizenship behaviors based on rewards and roles. Human Relations OnlineFirst, 63(10), pp. 1-23.

Masepy, Sharon Suri. (2016). The Impact Of Reward And Recognition On Employee Engagement At Pt. Bank Sulutgo, Manado. Jurnal Berkala Ilmiah Efisiensi, 16(1), Pp: 289-301.

Moorhead, Gregory dan Ricky W. Griffin. (2013). Perilaku Organisasi. Jakarta: Salemba Empat.

Nusatria, Sandi. (2011). "Employee Engagement: Anteseden dan Konsekuensi (Studi pada Unit CS PT. Telkom Indonesia Semarang)". Skripsi, Sarjana Jurusan Manajemen pada Universitas Diponogoro, Semarang.

Organ, D.W., Smith, C.A. and Near, J.P. (1983) .Organizational Citizenship Behavior. Its Nature, and Antecendent, Journal Of Applied Psychology, 68(4), pp.653-663. 
Paramita, Patricia Dhiana. (2012). Organizatinal Citizenship Behaviour (OCB): Aspek Dari Aktivitas Individual Dalam Bekerja. 10 (24), pp: 1412-8489.

Puspadewi, Ulfa Isnani. danSuharnomo. (2016). Analisis Tentang Employee Engagement Pada Perusahaan Jasa(Studi Pada Karyawan Patra Jasa Convention Hotel Semarang). Diponegoro Journal Of Management, 5(3), Hal: $1-14$

Riduwan dan Sunarto.(2007).Pengantar Statistik Untuk Penelitian Pendidikan, Sosial, Ekonomi dan Bisnis.Bandung : Alfabeta.

Rohma, N. (2011). Pengaruh Kepemimpinan, Komitmen Organisasi Dan Komunikasi Interpersonal Terhadap Organizational Citizenship Behavior (OCB) Karyawan Negeri Sipilpoliteknik Ilmu Pelayanan Semarang, Artikel Ilmiah. Program Pasca Sarjana Program Studi Megister ManajemenUniversitas Semarang.

Saradha, H. and Patrick, Harold Andrew. (2011). Employee Engagement in Relation to Organizational Citizenship Behavior in Information Technology Organizations. International Journal of Computer Applications (IJCA), 2(2), Pp. 74-90.

Schaufeli, W. B. and Bakker, A. B. (2003). Utrech work engagement scale preliminary manual version 1. Utrech University, Occupational Health Psychology Unit..

Schaufeli, W. B. and Bakker, A. B. (2010). Defining and measuring workengagement: Bringing clarity to the concept. (Electronic version). WorkEngagement A Handbook of Essential Theory and Research. New York..

Sinnappan, Lara Priyadharshini. andAmulraj, Mahadevan. (2014). Impact of Rewards and Recognition and Empowerment on Organizational Citizenship Behaviors among Technical Engineers. Management Studies and Economic Systems (MSES), 1 (2), Pp. 89-95.

Sridhar, Anusha. And Thiruvenkadam, T. 2014. Impact Of Employee Engagement On Organization Citizenship Behaviour.Bvimsr's Journal Of Management Research, 6(2), Pp: 147-155.

Tufail, Muhammad Shahid. Muneer, Saqib. Manzoor, Muhammad. (2017). How Organizational Rewards And Organizational Justice Affect The Organizational Citizenship Behavior And Counterproductive Work Behavior: Analysis Of Pakistan Service Industries. City University Research Journal, 1(2). Pp: 171-182

Vercic, Tkalac, A., Vercic, D. and Sriramesh, K. (2012).Internal communication.Definition, parameters, and the future. Public relations review, 38(2), pp. 223-230. 
Waspodo, Agung AWS dan Lussy Minadaniati. (2012). Pengaruh Kepuasan Kerja dan Iklim Organisasi Terhadap Organizational Citizenship Behavior (OCB) Karyawan PT. Trubus Swadaya.Jurnal Riset Manajemen Sains Indonesia (JRMSI), 3(1), h: 1-16.

Welch, M., and Jackson, P. R. (2007). Rethinking Internal Communication: A Stakeholder Approach. Corporate Communications: An International Journal, 12(9), Pp:177-198.

Yildirim, Osman. (2014). The Impact Of Organizational Communication On Organizational Citizenship Behavior: Research Findings. Procedia - Social And Behavioral Sciences, 1(50), Pp. 1095 - 1100. 